\title{
COMPARISON OF SOME PROPERTIES OF BUTTER OIL PRODUCED FROM CULTURED AND UNCULTURED BUTTER AT DIFFERENT TEMPERATURES
}

\author{
Tekin Demir, Seval Andiç* \\ University of Van Yüzüncü Y1l, Faculty of Engineering, Department of Food Engineering, Van, Turkey
}

Received / Geliş: 12.10.2020; Accepted / Kabul: 05.04.2021; Published online / Online bask1: 19.04.2021

Demir, T., Andic, S. (2021). Comparison of some properties of butter oil produced from cultured and uncultured butter at different temperatures. GIDA (2021) 46(3) 621-633 doi: 10.15237/gida.GD20118

Demir, T., Andiç, S. (2021). Kültürlü ve Kültürsüz Tereyağlarından Farklı Sıcaklıklarda Üretilen Sadeyağların Bazı Özelliklerinin Karşılaşturılması. GIDA (2021) 46(3) 621-633 doi: $10.15237 /$ gida.GD20118

\begin{abstract}
This study objective was to determine the effect of the use of culture and temperature applications in butter production on some properties of butter oil produced from these butter. Cultured (Group 1) and uncultured (Group 2) butter were processed into butter oil at 60,90 , and $120^{\circ} \mathrm{C}$ and were stored at $+4^{\circ} \mathrm{C}$ for 60 days. Analyses revealed that the acidity, water activity, thiobarbituric acid cholesterol, lipolysis values and the yeastmold and lipolytic microorganism counts of butter oil samples were lower than in the corresponding butter samples. At the end of the storage period, for both groups, the peroxide values of the butter oils produced at 60 and $90^{\circ} \mathrm{C}$ were lower than those of the counterpart butters, while the butter oils processed at $120^{\circ} \mathrm{C}$ had higher peroxide values. Raw matter, production temperature and storage time generally had a significant effect on the analyzed properties of butter oil.

Keywords: Butter, butter oil, cholesterol, lipolysis, oxidation

\section{KÜLTÜRLÜ VE KÜLTÜRSÜZ TEREYAĞLARINDAN FARKLI SICAKLIKLARDA ÜRETILLEN SADEYAĞLARIN BAZI ÖZELLİKLERINIIN KARŞILAŞTIRILMASI}

\section{ÖZ}

$\mathrm{Bu}$ çalışmada, tereyağı üretiminde kültür kullanımının ve farklı sıcaklık uygulamalarının bu tereyağlarından üretilen sadeyağlanın bazı özellikleri üzerine etkisinin belirlenmesi amaçlanmıştır. Kültür eklenen (kültürlü - Grup 1) ve kültür eklenmeyen (kültürsüz - Grup 2) kremalardan üretilen tereyağları, 60,90 ve $120^{\circ} \mathrm{C}^{\prime}$ de sadeyağa işlenmiş ve $+4^{\circ} \mathrm{C}^{\prime}$ de 60 gün depolanmıştır. Analiz sonuçları, her iki grup tereyağı örneğinde de asitlik, su aktivitesi, tiyobarbitürik asit (TBA), kolesterol, lipoliz değerleri ile maya ve küf ve lipolitik mikroorganizma sayılanının hammadde tereyağlarına göre daha düşük olduğunu göstermiştir. Depolama sonunda her iki grupta da 60 ve $90^{\circ} \mathrm{C}$ 'de üretilen sadeyağların peroksit değerleri aynı hammaddeden üretilen tereyağlarının peroksit değerlerinden daha düşükken, $120^{\circ} \mathrm{C}$ 'de işlenen sadeyağların peroksit değerleri üretildiği tereyağlarının peroksit değerlerine göre daha yüksek bulunmuştur. Hammadde, üretim sıcaklığ1 ve depolama süresi sadeyağın incelenen özellikleri üzerinde genellikle önemli bir etki yapmıştır.

Anahtar kelimeler: Tereyağı, sadeyağ, kolesterol, lipoliz, oksidasyon

\footnotetext{
*Corresponding author / Yazışmalardan sorumlu yazar

凶sevalandic@yyu.edu.tr, @ (+90) 4322251727 / 28187

息 $(+90) 4322251730$
}

Tekin Demir; ORCID no: 0000-0002-3813-1693

Seval Andiç; ORCID no: 0000-0002-8306-0222 


\section{INTRODUCTION}

Milk consists of a polydisperse structure; lactose, minerals, and vitamins exist in solution in milk serum, while proteins are found in colloidal form, and milk oil is an emulsion. However, milk is not comprised merely of a simple oil emulsion system in water; rather, fat globules found in emulsion form in milk serum possess a very complex membrane. The process of churning breaks down a substantial portion of these membrane structures, concentrating the milk fat and thus producing butter (Jenness, 1988).

Butter is a water emulsion in oil, possessing a solid consistency that can be produced from milk, yogurt, or cream (Spreer, 1998). Although a large portion of milk serum is removed during butter production, a certain amount of serum remains in the butter structure. The amount of water found in butter is limited to a maximum of $16 \%$ (Turkish Food Codex, 2005, Notification No. 2005/19). Although the water content of butter, which contains milk fat in a concentrated form, is much lower than in milk, butter nonetheless constitutes an ideal environment for microbial activity due to its high water activity (Fındık and Andiç, 2017). Thus, in many countries, storage stability is increased by processing butter into butter oil, which has much lower water content than the former, using traditional methods. In Turkey, butter oil is known as "sadeyağ" and as "maslee" or "samn" elsewhere in the Middle East, while in Ethiopia and India it is called "ghee". Its other names include "roghan" in Iran, "samin" in Sudan, "samna" in Egypt, and "samuli" in Uganda. According to the International Dairy Federation (IDF) standards, butter oil is defined containing at least $99.3 \%$ milk fat; this requirement increases to $99 \%$ for the Turkish Food Codex (IDF, 1997; Turkish Food Codex, 2005; Dhurvey et al., 2012; Findık and Andiç, 2017; Gemechu and Tola, 2017).

Butter oil is obtained by applying high heat to milk, cream, or butter, resulting in the removal of most of the buttermilk and solid matter phases; the amount and duration of heat applied during the production process vary by region (Sserunjogi et al., 1998; Findık and Andiç, 2017). Since there are no standards pertaining to raw ingredients or production techniques for the production of butter oil, latter properties also vary. Studies have shown that processing butter into butter oil offers a number of advantages as well as disadvantages. For example, butter oil has been reported to have lower water activity, cholesterol, and microbial counts than butter, but higher fat content. Butter oil has been found to have lower cholesterol levels compared to butter (Özkanlı and Kaya, 2007; Andiç and Findık, 2017), a noteworthy point considering that the health implications of the cholesterol content of dairy products remain a subject of intense debate. Depending on the processes and storage conditions involved, cholesterol oxidation products may also be formed in butter and butter oil (Sander et al., 1988; Sieber, 2005); these oxidation products may have physiologically harmful effects (Osada et al., 1993; Guardiola et al., 1996). However, high temperatures applied during the production of butter oil have been purported to cause the formation of cholesterol oxidation products, which studies have determined to occur at temperatures of $150{ }^{\circ} \mathrm{C}$ and above (NourrozZadeh and Appelqvist; 1988; Seçkin and Metin, 2005; Sieber, 2005).

One study reported that Sprague-Dawley rats who had $5 \%$ and $10 \%$ ghee added to their diets for two weeks to 2 months did not have exhibit statistically significant changes in serum total cholesterol and triglyceride levels (Dwivedi et al., 2002). In another study, no significant change was observed in serum cholesterol levels in Fischer inbred rats whose diets were supplemented with $10 \%$ ghee for four weeks, in that study, there was no change in levels of liver microsomal lipid peroxidation, a known factor in cardiovascular diseases and cancer (Sharma et al., 2010).

Butter oil is mainly processed from butter, with the heat treatment (Mehta, 2006; Dhurvey et al., 2012; Findık and Andiç, 2017; Gosewade et al., 2017). Therefore, the extent to which the raw butter properties and production temperature affect those of the resulting butter oil is a topic of primary importance. There are a few study investigating the effects of production 
temperatures on the properties of butter oil. Mor et al. (2018) reported that, no significant effect of ripening of cream and clarification temperature was observed on color value of ghee samples. In previous studies, it was observed that peroxide and thiobarbituric acid values increased in parallel with the increase in the temperatures applied post production (Kaya, 2000; Özkanlı and Kaya 2007). Previous studies have reported the results of analyses carried out to determine the properties of butter oil. However, the number of studies examining the effects of raw butter's properties and production temperature on the properties of butter oil is limited. The present study thus aimed to determine the effects of different temperatures $\left(60,90\right.$, and $\left.120^{\circ} \mathrm{C}\right)$ applied during production as well as the use of culture in raw butter production on some properties of butter.

\section{MATERIALS AND METHODS}

\section{Materials}

A cream containing $40 \%$ fat was used for the production of butter. The cream was divided into two parts for the two different groups. The first group cream was pasteurized for 1 minute at $85^{\circ} \mathrm{C}$ and after cooling to $21^{\circ} \mathrm{C}$ was inoculated with a starter culture (Lactococcus lactis subsp. lactis biovar. diacetylactis and Leuconostoc mesenteroides subsp. cremoris) at $1 \%$. Group 2 cream was used without being pasteurized and without the addition of starter culture. Both groups of cream were matured at $21^{\circ} \mathrm{C}$ for 12 hours and then churned. The two groups of butter obtained were then divided into three parts each, to be processed into butter oil at 60,90 , and $120^{\circ} \mathrm{C}$. The butters and butter oils produced from them at 3 different temperatures were stored at $+4^{\circ} \mathrm{C}$ for 60 days; the samples were analyzed at the beginning, $30^{\text {th }}$ and $60^{\text {th }}$ days of storage. The study was carried out with two replications and two parallels for each analysis.

\section{Methods}

\section{Chemical Analyses}

The fat and dry matter contents of the butters and the butter oils were determined using the International Organization for Standardization method (ISO, 2003). An AquaLAb LITE brand device (Decagon Devices, Inc., Washington,
USA) was used to determine the water activity values. The acidity values of the samples were determined according to the methods given in ISO (2012) and lipolysis (acid degree value) values were measured as per IDF (1991). Peroxide values were determined using the method described by Egan et al. (1981), while cholesterol values were evaluated according to the method of Searcy and Bergquist (1960).

For thiobarbituric acid analysis, sample absorbance values were read against blanks (Egan et al., 1981). Readings were taken according to the method described by Kristensen et al. (2001).

\section{Microbiological Analyses}

Mold-yeast and lipolytic microorganism counts were performed for the butter and butter oil samples. For this purpose, $10 \mathrm{~g}$ of each sample was taken and homogenized in $90 \mathrm{~mL}$ of $40^{\circ} \mathrm{C}$ physiological solutions. For mold-yeast counts, Potato Dextrose Agar (PDA) (Merck, Darmstadt, Germany) was used, with $\mathrm{pH}$ adjusted to 3.5, while for lipolytic microorganism counts Tributyrin Agar (TBA) (Merck, Darmstadt, Germany) was used. The Petri dishes were incubated for 7 days at $21^{\circ} \mathrm{C}$ for mold-yeast counts and 3 days at $30^{\circ} \mathrm{C}$ for lipolytic microorganisms. Logarithmic transformation was applied to the microorganism counts obtained as a result of incubation.

\section{Determination of Free Fatty Acids by Gas Chromatography}

The QP 2010 Ultra SHIMADZU brand GC-MS device was used for the analysis of free fatty acids. One $g$ of sample was taken and mixed with $3 \mathrm{~g}$ of anhydrous sodium sulfate. Next, $0.3 \mathrm{ml}$ of sulfuric acid $(2.5 \mathrm{~mol} / \mathrm{L})$ and $0.5 \mathrm{mg} / \mathrm{mL}$ from $1 \mathrm{~mL}$ of internal standards (C:5 and C:13) were added. The mixture was extracted three times with $3 \mathrm{ml}$ of ether/heptane (1:1) and the solvent was then transferred to a separate tube. Before the addition of the fat sample, the aminopropyl column was conditioned with $10 \mathrm{~mL}$ of heptane. The solvent was then passed through the aminopropyl column and the eluant received was passed through the same column for a second time to hold free fatty acids in the column. Neutral lipids were removed 
from the column by passing $10 \mathrm{~mL}$ of ether/heptane (1:1) through it. Free fatty acids were eluted with diethyl ether containing 0.3 $\mathrm{mL} / \mathrm{mL}$ formic acid and injected directly into the Gas Chromatography device (De Jong and Badings, 1990).

The injector temperature was $250^{\circ} \mathrm{C}$ in split mode $(1: 10)$. The initial oven temperature $\left(60{ }^{\circ} \mathrm{C}\right)$ increased to $240^{\circ} \mathrm{C}$ at $10{ }^{\circ} \mathrm{C} / \mathrm{min}$ and was maintained for $45 \mathrm{~min}$. Thermo Scientific FFA Capillary column (260x298P L: $30 \mathrm{~m}$ x $0.530 \mathrm{~mm}$, Film thickness: $0.25 \mu \mathrm{m}$, Thermo Scientific Cheshire, UK) was used in the separation of FFAs. Helium was used as the carrier gas at a flow rate of $2.6 \mathrm{~mL} / \mathrm{min}$.

\section{Statistical Analyses}

All data were subjected to variance analysis and differences between means were evaluated by Duncan multiple range test (significance $P<0.05$ ) using the SPSS software $(1999,2000)$. To gain insight into the structure of the data set, principal component analysis (PCA) was performed (Piggott and Sharman, 1986).

\section{RESULTS AND DISCUSSION}

The dry matter values for all butter oil samples exceeded $99 \mathrm{~g} / 100 \mathrm{~g}$. The fat values of the butter oil samples increased with respect to those of the raw butter samples regardless of the fat content latter from which the butter oils were derived (Table 1). However, the fat values of the butter oils produced at $60^{\circ} \mathrm{C}$ remained below the minimum value of $99 \%$ as specified by the Turkish Food Codex for butter oil; the fat values of butter oils produced at 90 and $120^{\circ} \mathrm{C}$ were above $99 \%$. These results are consistent with values reported in the literature (Sserunjogi, Abrahamsen and Narvhu, 1998; Findik and Andiç, 2017). The differences between the two groups of butter oils in fat and dry matter values were statistically insignificant $(P>0.05)$.

Comparing water activity values, lower values were observed for the butter oil samples than for their butter samples derived from the same raw ingredients (Table 1). Both butter oil sample groups showed decreased water activity values as a result of the high temperatures applied during production. Accordingly, the lowest water activity values for both groups were found in the butter oils produced at $120^{\circ} \mathrm{C}$ in both groups. Water, which is in the structure of the food and has of $0.2-0.8 \mathrm{aw}$, is associated with primarily hydrogen bonds with neighboring water molecules and solute molecules. Water has $0.8-1$ aw is usually hydrated in a monolayer on macro molecules such as proteins (Fennema, 1996). Butter oil samples produced at $120{ }^{\circ} \mathrm{C}$ generally have lower dry matter (Table 1) and total free fatty acid (Table 3) values than butter oil produced at 60 and $90{ }^{\circ} \mathrm{C}$ and butter samples. Therefor aw of butter oil samples produced $120^{\circ} \mathrm{C}$ is lower than butter and butter oil produced at 60 and $90{ }^{\circ} \mathrm{C}$. The temperatures applied during production were determined to have a significant effect $(P<0.05)$ on the water activity values of the samples (Table $1)$.

Butter oils produced at different temperatures from cultured and uncultured butter exhibited lower cholesterol values than their raw ingredients. The values obtained were consistent with those reported in the literature (Al-Khalifah and AI-Kahtani, 1993; Seçkin et al., 2005; Findık and Andiç 2017). The decreases observed in both butter oil groups correlated with increased production temperatures and the differences between the samples cholesterol values were statistically significant $(P<0.05)$. Some of the cholesterol, which is in the milk fat, in the fat globule membrane and a complex with the protein, is separated from the butter structure together with the solid matter during the production of butter oil. As can be seen in Table 1 , the maximum drymatter values are separated from the structure of butter oil samples produced at $120{ }^{\circ} \mathrm{C}$. Accordingly, the lowest cholesterol values were obtained from this group of butter oil. The cholesterol values of butter oils produced from cultured butter were significantly higher than those of butter oils produced from uncultured butter $(P<0.05)$. 
Table 1. Result of some chemical analysis of butter and butter oil

\begin{tabular}{|c|c|c|c|c|}
\hline & \multirow{2}{*}{$\begin{array}{c}\text { Sample } \\
\text { no }\end{array}$} & \multicolumn{3}{|c|}{ Storage Time (Days) } \\
\hline & & 0 & 30 & 60 \\
\hline \multirow{8}{*}{$\begin{array}{l}\text { Drymatter } \\
(\mathrm{g} / 100 \mathrm{~g}))\end{array}$} & 1 & $79.54 \pm 0.19 \mathrm{Ba}$ & $79.59 \pm 0.28 \mathrm{Ba}$ & $79.60 \pm 0.28 \mathrm{Ba}$ \\
\hline & 2 & $99.72 \pm 0.04 \mathrm{Aa}$ & $99.53 \pm 0.17$ Аа & $99.53 \pm 0.16 \mathrm{Aa}$ \\
\hline & 3 & $99.59 \pm 0.09 \mathrm{Aa}$ & $99.58 \pm 0.07 \mathrm{Aa}$ & $99.58 \pm 0.07 \mathrm{Aa}$ \\
\hline & 4 & $99.55 \pm 0.12 \mathrm{Aa}$ & $99.53 \pm 0.12 \mathrm{Aa}$ & $99.53 \pm 0.12 \mathrm{Aa}$ \\
\hline & 5 & $78.25 \pm 0.44 \mathrm{Ca}$ & $78.38 \pm 0.14 \mathrm{Ca}$ & $78.38 \pm 0.14 \mathrm{Ca}$ \\
\hline & 6 & $99.60 \pm 0.08$ Аа & $99.60 \pm 0.03$ Аа & $99.60 \pm 0.03 \mathrm{Aa}$ \\
\hline & 7 & $99.67 \pm 0.01 \mathrm{Aa}$ & $99.65 \pm 0.03 \mathrm{Aa}$ & $99.64 \pm 0.03 \mathrm{Aa}$ \\
\hline & 8 & $99.45 \pm 0.01 \mathrm{Ab}$ & $99.60 \pm 0.03$ Аа & $99.59 \pm 0.03 \mathrm{Aa}$ \\
\hline \multirow{8}{*}{$\begin{array}{l}\text { Fat } \\
(\mathrm{g} / 100 \mathrm{~g})\end{array}$} & 1 & $78.33 \pm 0.58 \mathrm{Ba}$ & $78.33 \pm 0.57 \mathrm{Ba}$ & $78.33 \pm 0.57 \mathrm{Ba}$ \\
\hline & 2 & $98.96 \pm 0.36 \mathrm{Aa}$ & $98.96 \pm 0.36 \mathrm{Aa}$ & $98.96 \pm 0.36 \mathrm{Aa}$ \\
\hline & 3 & $99.17 \pm 0.36 \mathrm{Aa}$ & $99.17 \pm 0.36$ Аа & $99.17 \pm 0.36 \mathrm{Aa}$ \\
\hline & 4 & $99.38 \pm 0.00 \mathrm{Aa}$ & $99.38 \pm 0.00 \mathrm{Aa}$ & $99.38 \pm 0.00 \mathrm{Aa}$ \\
\hline & 5 & $77.33 \pm 0.58 \mathrm{Ca}$ & $77.33 \pm 0.57 \mathrm{Ca}$ & $77.33 \pm 0.57 \mathrm{Ca}$ \\
\hline & 6 & $98.96 \pm 0.36 \mathrm{Ac}$ & $98.96 \pm 0.37$ Аа & $98.96 \pm 0.36 \mathrm{Aa}$ \\
\hline & 7 & $99.17 \pm 0.36 \mathrm{Aa}$ & $99.17 \pm 0.36 \mathrm{Aa}$ & $99.17 \pm 0.36 \mathrm{Aa}$ \\
\hline & 8 & $99.17 \pm 0.36 \mathrm{Aa}$ & $99.17 \pm 0.36$ Аа & $99.17 \pm 0.36 \mathrm{Aa}$ \\
\hline \multirow{8}{*}{$\begin{array}{l}\text { Water Activity } \\
\left(a_{w}\right)\end{array}$} & 1 & $0.98 \pm 0.04 \mathrm{Aa}$ & $0.96 \pm 0.01 \mathrm{Aa}$ & $0.96 \pm 0.01 \mathrm{Aa}$ \\
\hline & 2 & $0.77 \pm 0.01 \mathrm{Ca}$ & $0.76 \pm 0.01 \mathrm{Ca}$ & $0.76 \pm 0.01 \mathrm{Ca}$ \\
\hline & 3 & $0.72 \pm 0.02 \mathrm{Da}$ & $0.73 \pm 0.02 \mathrm{Da}$ & $0.72 \pm 0.02 \mathrm{Da}$ \\
\hline & 4 & $0.50 \pm 0.02 \mathrm{Ga}$ & $0.50 \pm 0.01 \mathrm{Ga}$ & $0.49 \pm 0.01 \mathrm{Ga}$ \\
\hline & 5 & $0.93 \pm 0.02 \mathrm{Ba}$ & $0.92 \pm 0.01 \mathrm{Ba}$ & $0.92 \pm 0.02 \mathrm{Ba}$ \\
\hline & 6 & $0.67 \pm 0.10 \mathrm{Ea}$ & $0.64 \pm 0.01 \mathrm{Ea}$ & $0.65 \pm 0.03 \mathrm{Ea}$ \\
\hline & 7 & $0.56 \pm 0.01 \mathrm{Fa}$ & $0.55 \pm 0.01 \mathrm{Fa}$ & $0.55 \pm 0.03 \mathrm{Fa}$ \\
\hline & 8 & $0.48 \pm 0.01 \mathrm{Ga}$ & $0.48 \pm 0.01 \mathrm{Ha}$ & $0.49 \pm 0.01 \mathrm{Ga}$ \\
\hline \multirow{8}{*}{$\begin{array}{l}\text { Cholesterol } \\
\text { (mg/100 g fat) }\end{array}$} & 1 & $303.26 \pm 3.04 \mathrm{Aa}$ & $300.47 \pm 2.55 \mathrm{ABa}$ & $300.79 \pm 4.82 \mathrm{Aa}$ \\
\hline & 2 & $292.86 \pm 7.40 \mathrm{Ba}$ & $293.60 \pm 2.33 \mathrm{BCa}$ & $291.72 \pm 3.47 \mathrm{Ba}$ \\
\hline & 3 & $289.27 \pm 1.06 \mathrm{Ba}$ & $287.03 \pm 6.50 \mathrm{Ca}$ & $287.31 \pm 2.49 \mathrm{Ba}$ \\
\hline & 4 & $255.79 \pm 0.68 \mathrm{Da}$ & $255.79 \pm 1.33$ Еа & $256.69 \pm 1.69 \mathrm{Da}$ \\
\hline & 5 & $302.61 \pm 2.44 \mathrm{Aa}$ & $302.66 \pm 1.38 \mathrm{Aa}$ & $302.14 \pm 5.52 \mathrm{Aa}$ \\
\hline & 6 & $291.36 \pm 1.09 \mathrm{Ba}$ & $291.33 \pm 2.47 \mathrm{Ca}$ & $291.03 \pm 1.18 \mathrm{Ba}$ \\
\hline & 7 & $277.06 \pm 4.06 \mathrm{Ca}$ & $275.12 \pm 8.32 \mathrm{Da}$ & $276.90 \pm 1.18 \mathrm{Ca}$ \\
\hline & 8 & $236.82 \pm 1.78 \mathrm{Ea}$ & $235.28 \pm 3.91 \mathrm{Fa}$ & $236.89 \pm 0.99 \mathrm{Ea}$ \\
\hline \multirow{8}{*}{$\begin{array}{l}\text { Acidity Value } \\
(\mathrm{mL} / 100 \mathrm{~g})\end{array}$} & 1 & $0.33 \pm 0.02 \mathrm{Ac}$ & $0.45 \pm 0.04 \mathrm{Ab}$ & $0.59 \pm 0.02 \mathrm{Aa}$ \\
\hline & 2 & $0.05 \pm 0.01 \mathrm{Cb}$ & $0.07 \pm 0.01 \mathrm{Cb}$ & $0.10 \pm 0.01 \mathrm{Ca}$ \\
\hline & 3 & $0.04 \pm 0.01 \mathrm{Ca}$ & $0.05 \pm 0.01 \mathrm{Ca}$ & $0.07 \pm 0.02 \mathrm{DCa}$ \\
\hline & 4 & $0.04 \pm 0.01 \mathrm{Ca}$ & $0.04 \pm 0.01 \mathrm{Ca}$ & $0.06 \pm 0.01 \mathrm{Da}$ \\
\hline & 5 & $0.24 \pm 0.02 \mathrm{Bb}$ & $0.33 \pm 0.06 \mathrm{Ba}$ & $0.40 \pm 0.04 \mathrm{Ba}$ \\
\hline & 6 & $0.05 \pm 0.01 \mathrm{Ca}$ & $0.06 \pm 0.01 \mathrm{Ca}$ & $0.06 \pm 0.01 \mathrm{DCa}$ \\
\hline & 7 & $0.03 \pm 0.01 \mathrm{Ca}$ & $0.04 \pm 0.01 \mathrm{Ca}$ & $0.04 \pm 0.01 \mathrm{Da}$ \\
\hline & 8 & $0.03 \pm 0.01 \mathrm{Ca}$ & $0.03 \pm 0.01 \mathrm{Ca}$ & $0.04 \pm 0.01 \mathrm{Da}$ \\
\hline
\end{tabular}

$\overline{a, b, c}$ : Means within a row and each category followed by the different letters are significantly differ $(P<0.05)$. A,B,C,D,E,F: Means within a column and each category followed by the different letters are significantly differ $(P<$ $0.05)$.

1: cultured butter, 2: butter oil produced cultured butter at $60^{\circ} \mathrm{C}, 3$ : butter oil produced cultured butter at $90^{\circ} \mathrm{C}, 4$ : butter oil produced cultured butter at $120^{\circ} \mathrm{C}, 5$ : uncultured butter, 6 : butter oil produced uncultured butter at $60^{\circ} \mathrm{C}$, 7: butter oil produced uncultured butter at $90^{\circ} \mathrm{C}, 8$ : butter oil produced uncultured butter at $120^{\circ} \mathrm{C}$ 
The acidity values of butter and butter oil samples increased during the storage period; the changes in acidity levels observed in the butter samples were statistically significant $(P<0.05)$. Comparing the acidity levels of the butter samples, those of the butter samples made from cultured cream were significantly higher than those processed from uncultured cream at all stages of analysis $(P$ $<0.05$ ) (Table 1). For both groups, although the acidity values of butter oils produced at $60^{\circ} \mathrm{C}$ were greater than those produced at 90 and $120^{\circ} \mathrm{C}$, the differences were mostly not statistically significant $(P<0.05)$ (Table 1). The acidity results obtained for the butter samples in our study were consistent with those determined by Çakmakçı et al. (2014). Sagdic et al. (2004) reported acidity values for butters obtained from goat, sheep, and cow's milk of $0.25,0.23$, and 0.24 , respectively, similar to those found for uncultured butters in the present study but lower than the acidity values of the cultured butters in our study. Regarding the acidity levels of butter oils, our values were lower than those reported by Findık and Andiç (2017).

Peroxide values (PV), which correlate with hydroperoxides formed at the initial stage of oxidation, have been determined to be typically higher in butter oils than in the butters containing the same raw ingredients. The peroxide values of the butter samples processed from cultured cream and the resulting butter oils were found to generally have higher peroxide values than the butter and butter oils produced from uncultured cream at both the beginning and end of the storage period. This finding can be explained by the fact that the oxidative stability of butter made from ripened cream using culture is lower than that of butter produced from uncultured cream (Spreer, 1998; Tavlaşlar-Hocalar, 2011). Significant increases were observed in all samples peroxide values as a result of storage (Table 2). In parallel with the high temperatures applied during butter oil production, the increase in PV values may be indicative of thermal oxidation (Nawar, 1996). Similar findings were reported by Özkanl1 and Kaya (2007) for butter oils produced from pasteurized and non-pasteurized milk and by Senel et al. (2011) for Yay1k butter produced from cow, sheep and goat yoghurt. The PV values of our butter and butter oil samples were as a rule lower than those reported by Findık and Andiç (2017) for butter samples obtained at local markets and the butter oils produced from them. The PV values of all samples tested herein were below the allowed limit of 10 meq $\mathrm{O}_{2} / \mathrm{kg}$ (Egan et al., 1981).

Thiobarbituric acid (TBA) testing is a measure of the amount of malondialdehyde in the samples that provides information about the secondary products of oxidation. According to one view, TBA is only malondialdehyde specific and is comprised of fatty acids containing at least three unsaturated bonds in malondialdehyde (Dahle et al., 1962). Another view holds that TBA is not only malondialdehyde specific and may also react with other aldehydes, browning reaction products, protein and sugar fragmentation products, and amino acids (Janero, 1969). The TBA values of all samples increased significantly during storage $(P<0.05)$ (Table 2). Similar results were reported by Özkanlı and Kaya (2007) for butter oil and Şimşek (2011) for butter. As with peroxide values, TBA values were higher in the butter produced from cultured cream than in butter produced from non-cultured cream. At the end of the storage period, the highest TBA values obtained were for the butter oils produced from the cultured butter at $60^{\circ} \mathrm{C}$ (Table 2). The TBA values of the butter oils analyzed in this study were consistent with the TBA values reported by Asha et al. (2015) for butter oil stored at temperatures of 6,32 , and $60^{\circ} \mathrm{C}$ for 21 days.

The acid degree values (ADV) for the butter oils and the butters from which they were derived were determined to differ significantly between the beginning and end of the storage period $(P<$ $0.05)$, with the values for all samples increasing during storage. Although the changes in ADV were not statistically significant during the storage period of butter oil produced from the cultured butter, for the butter oil made from uncultured butter, the changes observed in ADV during the storage period were generally statistically significant $(P<0.05)$. The ADV results obtained for the butter oils in our study were similar to those reported by Yadav and Srinivasan (1985) for butter oil. With regard to differences in ADV 
between butter and butter oil, the findings of Findık and Andiç (2017) were consistent those obtained in our study. Nonetheless, our ADV results in absolute terms were lower than those reported in their study.

Table 2. Results of lipolysis values, and microorganism counts of butter and butter oil samples

\begin{tabular}{|c|c|c|c|c|}
\hline & \multirow{2}{*}{ Sample no } & \multicolumn{3}{|c|}{ Storage Time (Days) } \\
\hline & & 0 & 30 & 60 \\
\hline \multirow{8}{*}{ 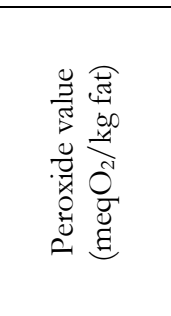 } & 1 & $0.92 \pm 0.01 \mathrm{Cc}$ & $1.52 \pm 0.01 \mathrm{Bb}$ & $1.67 \pm 0.11 \mathrm{BAa}$ \\
\hline & 2 & $0.91 \pm 0.04 \mathrm{Cc}$ & $1.12 \pm 0.01 \mathrm{~Eb}$ & $1.27 \pm 0.07 \mathrm{Ca}$ \\
\hline & 3 & $1.15 \pm 0.04 \mathrm{Bc}$ & $1.24 \pm 0.01 \mathrm{Db}$ & $1.57 \pm 0.02 \mathrm{Ba}$ \\
\hline & 4 & $1.57 \pm 0.02 \mathrm{Ac}$ & $1.70 \pm 0.01 \mathrm{Ab}$ & $1.76 \pm 0.01 \mathrm{Aa}$ \\
\hline & 5 & $0.74 \pm 0.49 \mathrm{Db}$ & $1.42 \pm 0.03 \mathrm{Ca}$ & $1.30 \pm 0.09 \mathrm{Ca}$ \\
\hline & 6 & $0.88 \pm 0.03 \mathrm{Cb}$ & $0.84 \pm 0.04 \mathrm{~Gb}$ & $1.14 \pm 0.05 \mathrm{Da}$ \\
\hline & 7 & $0.91 \pm 0.01 \mathrm{Cb}$ & $0.96 \pm 0.01 \mathrm{Fb}$ & $1.10 \pm 0.05 \mathrm{Da}$ \\
\hline & 8 & $1.23 \pm 0.11 \mathrm{Bc}$ & $1.45 \pm 0.03 \mathrm{Cb}$ & $1.62 \pm 0.07 \mathrm{Ba}$ \\
\hline \multirow{8}{*}{ 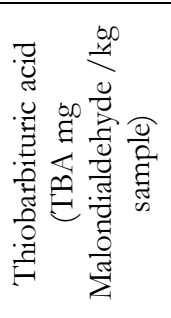 } & 1 & $0.13 \pm 0.01 \mathrm{Ac}$ & $0.17 \pm 0.01 \mathrm{Ab}$ & $0.20 \pm 0.01 \mathrm{Aa}$ \\
\hline & 2 & $0.04 \pm 0.01 \mathrm{Cc}$ & $0.06 \pm 0.01 \mathrm{Cb}$ & $0.09 \pm 0.01 \mathrm{Ba}$ \\
\hline & 3 & $0.04 \pm 0.01 \mathrm{Cb}$ & $0.06 \pm 0.01 \mathrm{Cba}$ & $0.07 \pm 0.01 \mathrm{CDEa}$ \\
\hline & 4 & $0.03 \pm 0.01 \mathrm{Cc}$ & $0.04 \pm 0.01 \mathrm{Cb}$ & $0.05 \pm 0.01 \mathrm{Ea}$ \\
\hline & 5 & $0.11 \pm 0.01 \mathrm{Bc}$ & $0.15 \pm 0.01 \mathrm{Bb}$ & $0.19 \pm 0.01 \mathrm{Aa}$ \\
\hline & 6 & $0.04 \pm 0.01 \mathrm{Cc}$ & $0.06 \pm 0.01 \mathrm{Cb}$ & $0.08 \pm 0.01 \mathrm{CBa}$ \\
\hline & 7 & $0.04 \pm 0.01 \mathrm{Cc}$ & $0.05 \pm 0.01 \mathrm{Cb}$ & $0.07 \pm 0.01 \mathrm{CDa}$ \\
\hline & 8 & $0.02 \pm 0.01 \mathrm{Cc}$ & $0.03 \pm 0.01 \mathrm{Cb}$ & $0.05 \pm 0.01 \mathrm{DEa}$ \\
\hline \multirow{8}{*}{ 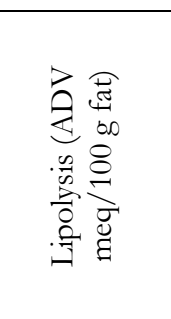 } & 1 & $1.70 \pm 0.08 \mathrm{Ab}$ & $1.84 \pm 0.07 \mathrm{Aab}$ & $1.96 \pm 0.11 \mathrm{Aa}$ \\
\hline & 2 & $0.31 \pm 0.07 \mathrm{Db}$ & $0.38 \pm 0.05 \mathrm{DEb}$ & $0.55 \pm 0.08 \mathrm{DCa}$ \\
\hline & 3 & $0.36 \pm 0.03 \mathrm{Dc}$ & $0.43 \pm 0.02 \mathrm{Db}$ & $0.52 \pm 0.03$ DEa \\
\hline & 4 & $0.31 \pm 0.02 \mathrm{Db}$ & $0.46 \pm 0.15 \mathrm{Dba}$ & $0.62 \pm 0.05 \mathrm{DCa}$ \\
\hline & 5 & $1.45 \pm 0.07 \mathrm{Ba}$ & $1.54 \pm 0.07 \mathrm{Ba}$ & $1.68 \pm 0.04 \mathrm{Ba}$ \\
\hline & 6 & $0.55 \pm 0.11 \mathrm{Ca}$ & $0.62 \pm 0.10 \mathrm{Ca}$ & $0.66 \pm 0.10 \mathrm{Ca}$ \\
\hline & 7 & $0.34 \pm 0.01 \mathrm{Da}$ & $0.40 \pm 0.03 \mathrm{DEa}$ & $0.41 \pm 0.07 \mathrm{FEa}$ \\
\hline & 8 & $0.24 \pm 0.04 \mathrm{Da}$ & $0.27 \pm 0.04 \mathrm{Ea}$ & $0.32 \pm 0.04 \mathrm{Fa}$ \\
\hline \multirow{8}{*}{ 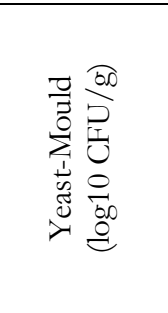 } & 1 & $1.58 \pm 0.06 \mathrm{Bb}$ & $1.74 \pm 0.10 \mathrm{Bb}$ & $2.17 \pm 0.07 \mathrm{Ba}$ \\
\hline & 2 & $\mathrm{ND}^{\mathrm{Ca}}$ & $\mathrm{ND}^{\mathrm{Ca}}$ & $\mathrm{NDCa}$ \\
\hline & 3 & $\mathrm{NDCa}^{\mathrm{Ca}}$ & $\mathrm{ND} \mathrm{Ca}$ & $\mathrm{ND}^{\mathrm{Ca}}$ \\
\hline & 4 & $\mathrm{ND}_{\mathrm{Ca}}$ & $\mathrm{ND} \mathrm{Ca}$ & $\mathrm{ND}^{\mathrm{Ca}}$ \\
\hline & 5 & $3.08 \pm 0.03 \mathrm{Ac}$ & $5.66 \pm 0.03 \mathrm{Ab}$ & $7.05 \pm 0.05 \mathrm{Aa}$ \\
\hline & 6 & $\mathrm{NDCa}$ & $\mathrm{NDCa}$ & $\mathrm{NDCa}$ \\
\hline & 7 & $\mathrm{ND}^{\mathrm{Ca}}$ & $\mathrm{ND} \mathrm{Ca}$ & $\mathrm{ND}^{\mathrm{Ca}}$ \\
\hline & 8 & $\mathrm{ND}^{\mathrm{Ca}}$ & $\mathrm{ND} \mathrm{Ca}$ & $\mathrm{ND}_{\mathrm{Ca}}$ \\
\hline \multirow{8}{*}{ 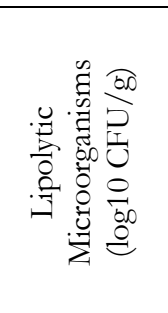 } & 1 & $4.66 \pm 0.04 \mathrm{Ba}$ & $4.69 \pm 0.04 \mathrm{Ba}$ & $4.61 \pm 0.06 \mathrm{Ba}$ \\
\hline & 2 & $2.54 \pm 0.06 \mathrm{Cb}$ & $2.94 \pm 0.05 \mathrm{Da}$ & $3.05 \pm 0.07 \mathrm{Da}$ \\
\hline & 3 & ND Ec & $2.17 \pm 0.15 \mathrm{~Eb}$ & $3.57 \pm 0.05 \mathrm{Ca}$ \\
\hline & 4 & $2.18 \pm 0.15 \mathrm{Db}$ & $3.28 \pm 0.06 \mathrm{Ca}$ & $3.54 \pm 0.07 \mathrm{Cc}$ \\
\hline & 5 & $6.98 \pm 0.03 \mathrm{Ab}$ & $7.12 \pm 0.04 \mathrm{Aa}$ & $6.72 \pm 0.07 \mathrm{Ac}$ \\
\hline & 6 & ND Ea & $\mathrm{NDFa}^{\mathrm{Fa}}$ & $\mathrm{ND} \mathrm{Fa}$ \\
\hline & 7 & ND Eb & $\mathrm{ND} F b$ & $2.59 \pm 0.05 \mathrm{Ea}$ \\
\hline & 8 & ND Ea & $\mathrm{ND} \mathrm{Fa}$ & $\mathrm{ND} F a$ \\
\hline
\end{tabular}

a,b,c: Means within a row and each category followed by the different letters are significantly differ $(P<0.05)$.

$\mathrm{A}, \mathrm{B}, \mathrm{C}, \mathrm{D}, \mathrm{E}, \mathrm{F}$ : Means within a column and each category followed by the different letters are significantly differ $(P<0.05)$. ND: Not detected; CFU: Colony forming unit.

1: cultured butter, 2: butter oil produced cultured butter at $60^{\circ} \mathrm{C}, 3$ : butter oil produced cultured butter at $90^{\circ} \mathrm{C}, 4$ : butter oil produced cultured butter at $120^{\circ} \mathrm{C}, 5$ : uncultured butter, 6 : butter oil produced uncultured butter at $60^{\circ} \mathrm{C}, 7:$ butter oil produced uncultured butter at $90^{\circ} \mathrm{C}, 8$ : butter oil produced uncultured butter at $120^{\circ} \mathrm{C}$ 
Mold and yeast counts for both butter types were observed to increase significantly over the storage period $(P<0.05)$ (Table 2$)$. The butter samples produced from cultured cream were statistically significantly lower with respect to mold and yeast counts than the butter samples processed from uncultured cream at the beginning and end of the storage period $(P<0.05)$. The process of pasteurization, applied to the cream prior to culturing, was effective. Neither mold nor yeast was detected in any of the butter oil samples.

Lipolytic microorganism counts were significantly higher in both groups of butter than in the butter oils produced from those them $(P<0.05)$. In both types of butter, the lipolytic microorganism counts decreased over the course of the storage period. These decreases were significant in the butter samples produced from uncultured cream $(P<0.05)$, while the decreases in the butter samples produced from cultured cream were not (Table 2). In samples of butter oil produced from cultured butter, the lipolytic microorganism counts were detectable, whereas lipolytic microorganisms could not be detected in any of sample except sample 7 in the butter oils, produced from uncultured butter. Similar results were reported by Fındık and Andiç (2017). The ability of some microorganisms to survive the thermal processes applied during the processing of butter oil can be attributed to the oil protecting microorganisms against the effect of the heat process and to the presence of water activity in butter oil (Ray and Bhunia, 2004). For this reason, the lipolytic microorganism counts for the butter oils produced from butter processed from cultured cream, which had higher water activity values, was greater in comparison with the other group.

The short, medium and long-chain fatty acid quantities of the samples increased throughout storage; these increases were for the most part significant $(P<0.05)$ (Table 3). For both groups, the short, medium, and long-chain free fatty acid levels of the butter samples were overall significantly higher than those of the corresponding butter oils $(P<0.05)$. This finding is explained by the lower acidity and water activity levels of the butter oils with respect to the butter samples, due to a monomolecular reaction between water and glycerides in lipids and the spontaneous and autocatalytic breakdown of esters and free acids in that environment. Secondly, as a result of the thermal processes applied, some of the lipase enzymes were inactivated, thus limiting both chemical and enzymatic hydrolysis (Nawar, 1996).

The differences between the total free fatty acid compounds of the butters and those of the butter oils processed from them were statistically significant for all periods of analysis $(P<0.05)$ (Table 3). In addition, the various temperatures used in production were determined to have a significant $(P<0.05)$ effect on the total free fatty acid content of butter oils in both groups. Similar results were reported by Iyer et al. (1967) for short, medium and long-chain free fatty acids. The total free fatty acid values for butter as determined in our study were consistent with those reported by Woo and Lindsay (1980) and Findık and Andiç (2017).

According to the principal component analysis results, principal components explained approximately $93.10 \%$ of the total variation on $0^{\text {th }}$ day of storage (first component $84.90 \%$, second component $8.30 \%$ ), approximately $92.90 \%$ on $30^{\text {th }}$ day of storage (first component $82.40 \%$, second component $10.40 \%$ ) and approximately $90.30 \%$ on the $60^{\text {th }}$ day of storage (first component $80.10 \%$, second component $10.20 \%$ ) (Figure 1).

There was a strong positive correlation between dry matter and fat throughout the storage period, and a strong negative correlation between dry matter, fat and water activity, mold and yeast counts, lipolytic microorganism counts. Again, for all analysis periods, there were strong positive correlations between ADV, total free fatty acids, and acidity, and between water activity, mold and yeast counts, and lipolytic microorganism counts. While a strong negative correlation between PV and TBA was observed at the beginning of storage, this negativity had decreased toward the end of the storage period. 
Table 3. Result of free fatty acids content of butter and butter oil

\begin{tabular}{|c|c|c|c|c|}
\hline & \multirow{2}{*}{$\begin{array}{c}\text { Sample } \\
\text { no }\end{array}$} & \multicolumn{3}{|c|}{ Storage Time (Days) } \\
\hline & & 0 & 30 & 60 \\
\hline \multirow{8}{*}{ 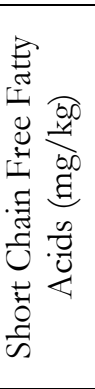 } & 1 & $50.69 \pm 1.76 \mathrm{Ac}$ & $316.01 \pm 1.85 \mathrm{Bb}$ & $686.07 \pm 1.53 \mathrm{Aa}$ \\
\hline & 2 & $26.18 \pm 0.95 \mathrm{Cb}$ & $27.08 \pm 1.30 \mathrm{DEb}$ & $31.12 \pm 0.94 \mathrm{Ca}$ \\
\hline & 3 & $27.44 \pm 2.60 \mathrm{CBb}$ & $35.78 \pm 0.75 \mathrm{Ca}$ & $37.18 \pm 1.81 \mathrm{Ca}$ \\
\hline & 4 & $21.24 \pm 0.96 \mathrm{Db}$ & $22.75 \pm 0.95^{\mathrm{Eab}}$ & $24.38 \pm 1.04 \mathrm{Ca}$ \\
\hline & 5 & $52.45 \pm 3.01 \mathrm{Ac}$ & $390.11 \pm 8.44 \mathrm{Ab}$ & $599.30 \pm 4.39 \mathrm{Ba}$ \\
\hline & 6 & $27.57 \pm 0.96 \mathrm{CBc}$ & $30.98 \pm 1.02 \mathrm{CDb}$ & $33.44 \pm 1.01 \mathrm{Ca}$ \\
\hline & 7 & $30.16 \pm 1.13 \mathrm{Bc}$ & $32.70 \pm 0.95 \mathrm{CDb}$ & $35.52 \pm 1.65 \mathrm{Ca}$ \\
\hline & 8 & $29.26 \pm 0.98 \mathrm{CBc}$ & $31.92 \pm 0.71 \mathrm{CDb}$ & $33.79 \pm 0.36 \mathrm{Ca}$ \\
\hline \multirow{8}{*}{ 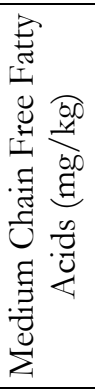 } & 1 & $294.02 \pm 7.98 \mathrm{Bc}$ & $956.95 \pm 12.09 \mathrm{Ab}$ & $2352.31 \pm 19.61 \mathrm{Aa}$ \\
\hline & 2 & $217.41 \pm 3.02 \mathrm{Cc}$ & $264.99 \pm 3.25 \mathrm{Bb}$ & $298.82 \pm 6.14 \mathrm{Ga}$ \\
\hline & 3 & $190.64 \pm 1.21 \mathrm{Ec}$ & $207.57 \pm 5.85 \mathrm{Ca}$ & $212.40 \pm 5.32 \mathrm{Da}$ \\
\hline & 4 & $191.17 \pm 1.49 \mathrm{~Eb}$ & $198.74 \pm 2.42 \mathrm{Ca}$ & $202.33 \pm 5.97 \mathrm{Ha}$ \\
\hline & 5 & $307.16 \pm 7.23 \mathrm{Ac}$ & $976.71 \pm 7.25 \mathrm{Ab}$ & $1650.21 \pm 15.71 \mathrm{Ba}$ \\
\hline & 6 & $202.14 \pm 3.66 \mathrm{Dc}$ & $275.56 \pm 4.23 \mathrm{Bb}$ & $300.05 \pm 7.53$ Еа \\
\hline & 7 & $193.53 \pm 1.79 \mathrm{Ec}$ & $199.56 \pm 3.42 \mathrm{Cb}$ & $209.85 \pm 1.35 \mathrm{Fa}$ \\
\hline & 8 & $190.52 \pm 6.76^{\mathrm{Eb}}$ & $201.95 \pm 3.69 \mathrm{Ca}$ & $209.73 \pm 4.42^{\mathrm{Ca}}$ \\
\hline \multirow{8}{*}{ 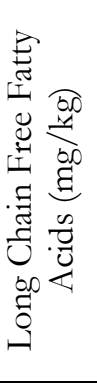 } & 1 & $4427.58 \pm 81.32$ Ас & $5469.46 \pm 42.92 \mathrm{Ab}$ & $8327.97 \pm 85.30 \mathrm{Aa}$ \\
\hline & 2 & $2726.63 \pm 67.95 \mathrm{Bc}$ & $2896.27 \pm 56.27 \mathrm{Bb}$ & $3825.82 \pm 60.00 \mathrm{Ca}$ \\
\hline & 3 & $2545.46 \pm 66.11 \mathrm{Cc}$ & $2810.58 \pm 65.74 \mathrm{BCb}$ & $3500.59 \pm 63.39 \mathrm{Da}$ \\
\hline & 4 & $2451.04 \pm 31.87 \mathrm{Cc}$ & $2706.63 \pm 40.94 \mathrm{Cb}$ & $3262.89 \pm 41.78 \mathrm{Da}$ \\
\hline & 5 & $4545.58 \pm 68.13$ Ас & $5523.23 \pm 68.95 \mathrm{Ab}$ & $7323.63 \pm 71.93^{\mathrm{Ba}}$ \\
\hline & 6 & $2224.14 \pm 29.82 \mathrm{Dc}$ & $2391.34 \pm 57.82 \mathrm{DEb}$ & $2686.78 \pm 72.91 \mathrm{Ca}$ \\
\hline & 7 & $2228.82 \pm 35.20 \mathrm{Dc}$ & $2472.78 \pm 57.80 \mathrm{Db}$ & $2735.11 \pm 95.26 \mathrm{Da}$ \\
\hline & 8 & $2184.90 \pm 61.74 \mathrm{Db}$ & $2326.96 \pm 57.77 \mathrm{~Eb}$ & $2672.22 \pm 65.64 \mathrm{Da}$ \\
\hline \multirow{8}{*}{ 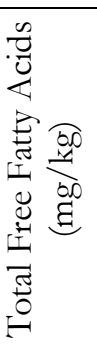 } & 1 & $4772.29 \pm 79.04 \mathrm{Bc}$ & $6742.41 \pm 32.77 \mathrm{Ab}$ & $11366.11 \pm 55.41^{\mathrm{Aa}}$ \\
\hline & 2 & $2970.23 \pm 65.59 \mathrm{Cc}$ & $3188.35 \pm 50.69 \mathrm{Bb}$ & $4155.77 \pm 56.69 \mathrm{Ca}$ \\
\hline & 3 & $2763.55 \pm 62.64 \mathrm{Dc}$ & $3053.93 \pm 60.03 \mathrm{BCb}$ & $3750.16 \pm 66.04 \mathrm{Da}$ \\
\hline & 4 & $2663.47 \pm 30.99 \mathrm{Dc}$ & $2928.12 \pm 39.16 \mathrm{Cb}$ & $3490.60 \pm 36.46 \mathrm{Ea}$ \\
\hline & 5 & $4905.19 \pm 64.90 \mathrm{Ac}$ & $6762.29 \pm 64.95 \mathrm{Ab}$ & $9573.14 \pm 54.06 \mathrm{Bа}$ \\
\hline & 6 & $2454.26 \pm 25.35 \mathrm{Ec}$ & $2697.88 \pm 56.28 \mathrm{Db}$ & $3020.27 \pm 79.12 \mathrm{Fa}$ \\
\hline & 7 & $2452.51 \pm 26.49 \mathrm{Ec}$ & $2705.04 \pm 57.89 \mathrm{Db}$ & $2980.48 \pm 96.29 \mathrm{Fa}$ \\
\hline & 8 & $2404.68 \pm 56.76 \mathrm{~Eb}$ & $2560.84 \pm 54.76 \mathrm{~Eb}$ & $2915.74 \pm 62.98 \mathrm{Fa}$ \\
\hline
\end{tabular}

a,b,c: Means within a row and each category followed by the different letters are significantly differ $(P<0.05)$. A,B,C,D,E,F,G: Means within a column and each category followed by the different letters are significantly differ $(P<$ $0.05)$.

1: cultured butter, 2: butter oil produced cultured butter at $60^{\circ} \mathrm{C}, 3$ : butter oil produced cultured butter at $90^{\circ} \mathrm{C}, 4$ : butter oil produced cultured butter at $120^{\circ} \mathrm{C}, 5$ : uncultured butter, 6 : butter oil produced uncultured butter at $60^{\circ} \mathrm{C}$, 7: butter oil produced uncultured butter at $90^{\circ} \mathrm{C}, 8$ : butter oil produced uncultured butter at $120^{\circ} \mathrm{C}$ 


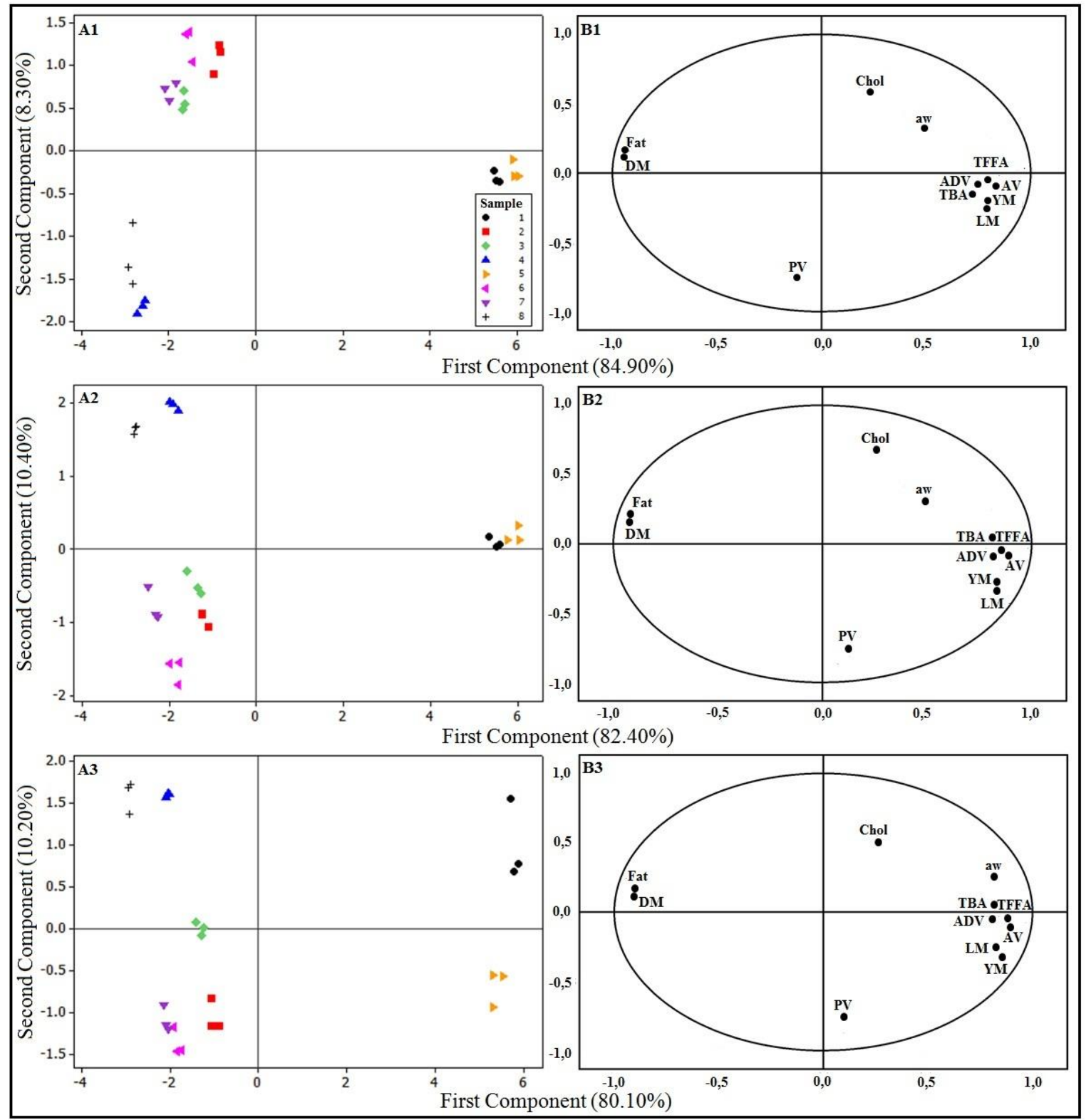

Fig. 1. PCA sample map (A1, A2, A3) and factors correlation circle (B1, B2, B3) of butter oil produced from cultured and uncultured butter at different temperatures with all chemical and microbiological

characteristic. A1, B1: 0. day of storage; A2, B2: 30. day of storage; A3, B3: 60. day of storage.

$\mathrm{ADV}=$ acid degree value; $\mathrm{AV}=$ acidity value; $\mathrm{a}_{\mathrm{w}}=$ water activity $\mathrm{Chol}=$ cholesterol value; $\mathrm{Fat}=$ fat value; $\mathrm{TFFA}$ $=$ total free fatty acids; $\mathrm{YM}=$ yeast-mould; $\mathrm{PV}=$ peroxide value; $\mathrm{TBA}=$ Thiobarbituric acid value; $\mathrm{LM}=$ lipolytic microorganism

\section{CONCLUSION}

Based on the results of the analyses, the ripening of the cream by using a starter culture, the different temperatures applied and the storage time were all determined to affect various properties of the butter oils. The temperatures used in the production of butter oil were shown to significantly affect their fat, water activity, and cholesterol contents. In both groups, the lowest water activity and cholesterol contents and highest fat values were observed in butter oils processed at $120^{\circ} \mathrm{C}$. The use of starter in butter 
production and the different temperatures applied during its production significantly affected the PV values of the butter oils. The TBA values for all samples increased significantly over time. However, the different temperature levels used in production did not significantly affect the TBA values of butter oils. No mold or yeast was detected in any analysis period in any of the butter oil samples. However, the number of lipolytic microorganisms in Group 1 samples (Butter oil produced cultured butter) was higher than that of Group 2 samples (Butter oil produced uncultured butter) for all analysis periods. Pasteurizing the cream to be processed in butter and ripening it using a starter is especially necessary from the standpoint of microbiological quality. However, the results of the present study indicate that neither the use of a starter in the production of raw butter nor pasteurization was necessary since thermal processes were applied during the preparation of the butter oils.

\section{ACKNOWLEDGEMENT}

This work was supported by the Scientific Research Projects Coordination Unit of Van Yuzuncu Yil University (Van, Turkey) under number of FDK-2017-6331.

\section{CONFLICT OF INTEREST}

The authors declare that there is no conflict of interest regarding the publication of this article.

\section{AUTHOR CONTRIBUTIONS}

Tekin Demir contributed to the production of samples, methodology, data acquisition, formal analysis, writing-original draft of the article. Seval Andiç had supervising the course of the project and contributed to conceptualization, methodology, formal analysis, writing-original draft, writing-review and editing, visualization as a supervisor. The authors read and approved the final version of the article.

\section{REFERENCES}

Al-Khalifah, A., Al-Kahtani, H. (1993). Composition of ghee (Samn Barri's) from cow's and sheep's milk. Food Chem., 46(4): 373-375, doi: 10.1016/0308-8146(93)90007-3.
Asha, A., Manjunatha, M., Rekha, R. M., Surendranath, B., Heartwin, P., Rao, J., Magdaline, E., Sinha, C. (2015). Antioxidant activities of orange peel extract in ghee (butter oil) stored at different storage temperatures. J. Food Sci. Technol., 52(12): 8220-8227, doi: 10.1007/s13197-015-1911-3.

Çakmakçı, S., Gündoğdu, E., Dağdemir, E., Erdoğan, Ü. (2014). Investigation of the possible use of Black Cumin (Nigella sativa L.) essential oil on butter stability. Kafkas Univ. Vet. Fak. Derg., 20(4): 533-539, doi: 10.9775/kvfd.2013.10550.

Dahle, L. K., Hill, E. G., Holman, R. T. (1962). The thiobarbituric acid reaction and the autoxidations of polyunsaturated fatty acid methyl esters. Arch. Biochem. Biophys., 98(2): 253-261, doi: 10.1016/0003-9861(62)90181-9.

De Jong, C., Badings, H. T., (1990). Determination of free fatty acids in milk and cheese procedures for extraction, clean up, and capillary gas chromatographic analysis. J. High Resolut. Chromatogr., 13: 94-98, doi: 10.1002/jhrc.1240130204.

Dhurvey, Y. R., Kawtikwar, P. S., Sakarkar, D. M. (2012). Evaluation of physicochemical properties of cow ghee before and after hydrogenation. Int. J. ChemTech Res., 4(1): 185-189.

Dwivedi, C., Crosser, A. E., Mistry, V. V., Sharma, H. M. (2002). Effects of dietary ghee (clarified butter) on serum lipids in rats. J. Appl. Nutr., 52: 65-68.

Egan, H., Kirk, R. S., Sawyer, R., (1981). Oils and fats. In: Pearson's Chemical Analysis of Foods, Egan, H. (Ed.), Churchill Livingstone, Edinburg, pp. 534-539.

Fennema, O. R. (1996). Water and ice. In: Food Chemistry, Fennema, O. R. (Ed.). (3rd ed) Marcel Dekker Inc., New York, pp. 17-95.

Findık, O., Andiç, S. (2017). Some chemical and microbiological properties of the butter and the butter oil produced from the same raw material. LWT, $\quad 86: \quad 233-239, \quad$ doi: 10.1016/j.lwt.2017.08.002.

Gemechu, A. T., Tola, Y. B. (2017). Traditional butter and ghee production, processing and 
handling in Ethiopia: A review. Afr. J. Food Sci., 11(4): 95-105, doi: 10.5897/AJFS2016.1544.

Gosewade, S., Gandhi, K., Ranvir, S., Kumar, A., Lal, D. (2017). A study on the physico-chemical changes occurring in ghee (butter oil) during storage. Indian J. Dairy Sci., 70(1): 81-88.

Guardiola, F., Codony, R., Addis, P. B., Rafecas, M., Boatella, J. (1996) Biological effects of oxysterols: current status. Food Chem. Toxicol., 34(2): 193-211, doi: 10.1016/02786915(95)00094-1.

IDF (1997). Anhydrous milkfat, anhydrous butter oil or anhydrous butterfat, butter oil or butterfat, ghee: Standards of identity. FIL-IDF 68A. Brussels, Belgium: International Dairy Federation.

ISO (2003). Butter-Determination of moisture, non-fat solids and fat contents. ISO 3727-3:2003 (IDF 80-3:2003).3.

ISO (2012). Milk and milk productsDetermination of the titratable acidity of milk fat. ISO/TS 22113:2012 (IDF/RM 204:2012).4.

Iyer, M., Richardson, T., Amundson, C. H., Boudreau, A. (1967). Improved Technique for Analysis of Free Fatty Acids in Butteroil and Provolone Cheese. J. Dairy Sci., 50(3): 285-291, doi: 10.3168/jds.S0022-0302(67)87411-3.

Janero, D. (1990). Malondialdehyde and thiobarbituric acid-reactivity as diagnostic indices of lipid peroxidation and peroxidative tissue injury. Free Radic. Biol. Med., 9(6): 515-540, doi: 10.1016/0891-5849(90)90131-2.

Jenness, R. (1988). Composition of milk. In: Fundamentals of dairy chemistry, N. P. Wang, N. P. (Ed.), New York, the USA, pp. 1-39.

Kristensen, D., Hansen, E., Arndal, A., Trinderup, R. A., Skibsted, L. H. (2001). Influence of light and temperature on the colour and oxidative stability of processed cheese. Int. Dairy J., 11: 837-843, doi: 10.1016/S09586946(01)00105-4.

Mehta, B. M. (2006). Ragi (Eleusine coracana L.) - a natural antioxidant for ghee (butter oil). Int. J.
Food Sci. Technol., 41 (Supplement 1): 86-89, doi: 10.1111/j.1365-2621.2006.01348.x.

Nawar, W. W. (1996). Lipids. In: Food chemistry, Fennema, O. R. (chief ed.), New York, the USA, pp. 225-331.

Nourooz-Zadeh, J., Appelqvist, L. A. (1988). Cholesterol oxides in swedish foods and food ingredients: Butter and Cheese. J. Am. Oil Chem. Soc., 65: 1635-1641, doi: 10.1007/BF02912568.

Osada, K., Kodama, T., Yamada, K., Sugano, M. (1993). Oxidation of cholesterol by heating. J. Agric. Food Chem., 41: 1198-1202, doi: $10.1021 /$ jf00032a006.

Özkanl1, O., Kaya, A. (2007). Storage stability of butter oil produced from sheep's non-pasteurized and pasteurized milk. Food Chem., 100: 1026-1031, doi: 10.1016/j.foodchem.2005.10.052.

Piggott, J. R., Sharman, K. (1986). Methods to aid interpretation of multidimensional data. In: Statistical Procedures in Food Research, Piggott, J. R. (ed.), Elsevier Applied Science, London, the UK, pp. 181-233.

Ray, B., A Bhunia, A. (2007). Fundamental food microbiology. New York, CRC Press, 663.

Sagdic, O., Donmez, M., Demirci, M. (2004). Comparison of characteristic and fatty acid profiles of Traditional Turkish Yayik butters produced from goats', ewes' or cows' milk. Food Control, 15(6): 485-490, doi: 10.1016/j.foodcont.2003.07.003.

Sander, B. D., Smith, D. E., Addis, P. B. (1988). Effects of Processing Stage and Storage Conditions on Cholesterol Oxidation Products in Butter and Cheddar Cheese. J. Dairy Sci., 71: 31733178, doi: 10.3168/jds.S0022-0302(88)79921-X.

Searcy, R. L., Bergquist, L. M., (1960). A new color reaction for the quantitation of serum cholesterol. Clin. Chem., 5: 102, doi: 10.1016/0009-8981(60)90035-8.

Seçkin, A. K., Gursoy, O., Kinik, O., Akbulut, N. (2005). Conjugated linoleic acid (CLA) concentration, fatty acid composition and cholesterol content of some Turkish dairy 
products. $\quad L W T, \quad 38(8): \quad 909-915$, doi: 10.1016/j.lwt.2004.09.011.

Seçkin, A. K., Metin, M. (2005). The effect of process temperature and time on the occurrence of the products of cholesterol oxidation in butter. Int. J. Food Sci. Technol, 40: 903-906, doi: 10.1111/j.1365-2621.2005.01022.x.

Senel, E., Atamer, M., Öztekin, F. S. (2011). The oxidative and lipolytic stability of Yaylk butter produced from different species of mammals milk (cow, sheep, goat) yoghurt. Food Chem., 127(1): 333-339, doi: 10.1016/j.foodchem.2011.01.012.

Sharma, H., Zhang, X., Dwivedi, C. (2010). The effect of ghee (clarified butter) on serum lipid levels and microsomal lipid peroxidation. $A Y U, 31(2)$ : 134-140, doi: 10.4103/0974-8520.72361.

Sieber, R. (2005). Oxidised cholesterol in milk and dairy products. Int. Dairy J., 15(3): 191-206, doi: 10.1016/j.idairyj.2004.07.013.

Sonia Mor, S., Sharma, V., Minz, P. S., Nain, N. 2018. Temperature and ripening of cream on color parameters of ghee. Int. J. Curr. Microbiol. App. Sci., 7(10): 30-43, doi: 10.20546/ijcmas.2018.710.005.

Spreer, E. (1998). Milk and dairy product technology, Marcel Decker Inc., New York, the USA, pp. 483.

SPSS, (1999). SPSS Inc. Released 1999. SPSS for Windows, Version 10. Chicago: SPSS Inc.
Sserunjogi, M. L., Abrahamsen, R. K., Narvhu, J. (1998). A review paper: Current knowledge of ghee and related products. Int. Dairy J., 8: 677-688, doi: 10.1016/S0958-6946(98)00106-X.

Şimşek, B. (2011). Studies on the storage stability of yayik butter. J. Verbrauch. Lebens., 6: 175-181, doi: 10.1007/s00003-010-0622-y.

Tavlaşlar-Hocalar, B., (2011). Tereyă̆̆ Teknolojisi, Ege Univ. Publisher, İzmir, Türkiye, s. 120.

Turkish Food Codex. (2005). Notification No. 2005/19 on butter, milk butter based products and clarified butter, 12 April 2005 [LEXFAOC108244].

Woo, A. H., Lindsay, R. C. (1980). Method for the Routine Quantitative Gas Chromatographic Analysis of Major Free Fatty Acids in Butter and Cream. J. Dairy Sci., 63: 1058-1064, doi: 10.3168/jds.S0022-0302(80)83047-5.

Yadav, J. S., Srinivasan, R. A. (1985). Effect of ripening cream with Streptococcus lactis subsp. diacetilactis on the flavour of ghee (clarified butterfat). J. Dairy Res., 52(4): 547-553, doi: 10.1017/S002202990002450X. 